\title{
MEASUREMENT OF NITRATE ADSORPTION CAPACITIES WITH DIFFERENT SOILS - A COLUMN TRACER STUDY
}

\author{
Mallikarjun.S.D, Ramesh.Bashetty, Dr.SR.Mise \\ Department of Civil \& Environmnet Engg \\ PDA College of Engineering, Kalaburagi, Karnataka, India
}

\begin{abstract}
In most mineral pollution episodes, several minerals are released simultaneously into the environment and it is of crucial importance to know the retention of a metal in detriment of another. Due to increased use of pesticides and fertilizers, Nitrates are accumulating into soil and leaching into groundwater thereby contaminating both soil and water. Agriculture, including commercial livestock and poultry farming is the source of many organic and inorganic pollutants in surface waters and groundwater. These contaminants include both sediment from erosion cropland and compounds nitrogen that partly originate in animal wastes and commercial fertilizers. Animal wastes are high in oxygen demanding material, nitrogen and this often harbor pathogenic organisms. Keeping the above points in view a nitrate adsorption study was planned. In the present study a series of soil column tracer experiments were conducted with two different soils, namely black cotton and red soil. From the discussions it can be attributed that the column tracer experiment with black cotton soil takes less time to reach equilibrium than red soil. Similarly from the both Langmuir and Freundlich isotherms it is evident that the retardation factor is affected by the percentage fines available in soil. If the percentage fines of the soil are more than the adsorption capacity will be more. Finally black cotton soil shows good removal efficiency and hence it can be used as adsorbents.
\end{abstract}

Keywords - Nitrate (No3-) adsorption, sorption, isotherm, retardation factor, column tracer experiment

\section{INTRODUCTION}

In an entire cultural history, man is facing one of the most horrible ecological crises - the problem of polluting the environment, which in the past was pure, virgin, undisturbed, uncontaminated and basically quite hospitable. There are many sources of nitrate in the environment, including deposition from the atmosphere, decomposition of plant and animal material, sewage, manures and chemical fertilizers. Nitrate is one of the more common forms of nitrogen in the environment. The relationship between these sources and the mechanisms by which nitrate travels through the environment is complex.

It is an essential nutrient for plant growth but too much nitrate can contaminate groundwater which we use as a source of drinking water or can affect the quality of aquatic habitat such as our rivers, streams and estuaries. The residues of fertilizers, pesticides and irrigation water in one hand, increased agricultural production; while, on the other hand, created adverse impact on soil and water bodies. Many causes of pollution including sewage and fertilizers contain nutrients as nitrates. Nitrate plays an important role in the health of our fresh surface bodies and also our estuaries. Nitrogen is one of the key nutrients for the growth of aquatic plants, and thus an important link in the food chain. Like anything else, however, there can be too much of a good thing. Nitrate levels in both groundwater and surface water have been increasing over a long period of time, and it is unlikely that these trends can be reversed quickly. At the same time, a great deal of study had been devoted to understanding the sources, behaviour and distribution of nitrate in the environment. This information will assist in the development of effective strategies to reduce the impact of nitrate on our environment.

Excessive nutrient levels in combination with a number of other factors can lead to an overabundance of some aquatic plant species in our estuaries. This rapid growth of some plant species upsets the natural balance of the ecosystem. In addition, as this abundant plant material dies and decomposes, it consumes oxygen, sometimes stripping all of the oxygen from the water, causing the death of shellfish and plants and producing very obnoxious odours. When precipitation falls to the ground, some of it evaporates, some runs off quite quickly into streams, ponds and the ocean and a large portion (about $30-35 \%$ ) soaks into the ground and becomes groundwater. This groundwater in turn 'discharges' slowly back to the surface through springs and directly into surface water bodies and makes up almost two-thirds of the water. During dry times of the year, this groundwater discharge makes up almost all the water in our streams. When this discharging groundwater is rich in nitrate, it represents the dominant pathway by which nitrate from the land surface is transported to our water ways. 


\section{International Journal of Engineering Applied Sciences and Technology, 2019 \\ Vol. 4, Issue 5, ISSN No. 2455-2143, Pages 486-492 \\ Published Online September 2019 in IJEAST (http://www.ijeast.com)}

Nitrate is a problem as a contaminant in drinking water (primarily from groundwater and wells) due to its harmful biological effects. High concentrations can cause methemoglobinemia, and have been cited as a risk factor in developing gastric an intestinal cancer. Due to these health risks, a great deal of emphasis has been placed on finding effective treatment processes to reduce nitrate concentrations to safe levels. An even more important facet to reduce the problem is prevention measures to stop the leaching of nitrate from the soil. Some researchers suggest that reducing the amount of fertilizers used in agriculture will help to alleviate the problem and may not hurt crop yields. Other new developments in leach pits and slurry stores help to control the nitrate that comes from stored manure. By installing these prevention methods and reducing the amount of fertilizer used, the concentration of nitrate in the groundwater can be reduced over time. Treatment processes, such as ion exchange can have an immediate effect on reducing levels in drinking water. These processes do not remove the entire nitrate, but can help to bring the concentration down to the suggested level of $10 \mathrm{mg} / \mathrm{l}$.

The most common groundwater contaminants in rural areas can create serious problems, such as eutrophication and outbreaks of infectious diseases when released into the environment (Ahlgren et al 2008). Contamination of drinking water by nitrates can cause potential hazards to human health. Excess nitrate in drinking water may cause blue-baby syndrome, which results from the conversion of hemoglobin into methaemoglobin, which cannot carry oxygen (Fewtrell 2004). Traditional methods for removal of nitrates from water include two main groups of treatment processes: biological and physico-chemical. Biological denitrification is an ecofriendly and cost - effective method by which facultative anaerobic denitrifying bacteria reduce nitrate or nitrite into harmless nitrogen gas in the absence of oxygen (Rijn et al 2006). The biological denitrification process is slow, particularly for industrial wastewater containing high concentrations of nitrate and for low temperatures. The most conventional physico-chemical processes for nitrate removal are ion exchange (Ghafari et al 2008), reverse osmosis (Shrimali and Singh 2001), electro dialysis (Rautenbach et al 1986), metallic ironaided abiotic nitrate reduction (Summers and Chang 1993) and adsorption (Ozturk and Bektas 2004). in section

II. Experimental results are presented in section III. Concluding remarks are given in section IV.

\section{PROPOSED WORK}

In this present study, a series of column tracer experiments were conducted to observe the retention and leaching of contaminant (nitrate) through the soil media. In order to conduct the tests, an experimental apparatus was planned and developed.

\section{Test Set Up}

The typical column tracer equipment/ soil column equipment set up is shown in Fig. 1 and also various accessories of set up are indicated in the order. Test set up typically consists of the following accessories are Fiber column, Storage tank, Flexible tube, Flow adjusting clamp, Air removing valve.

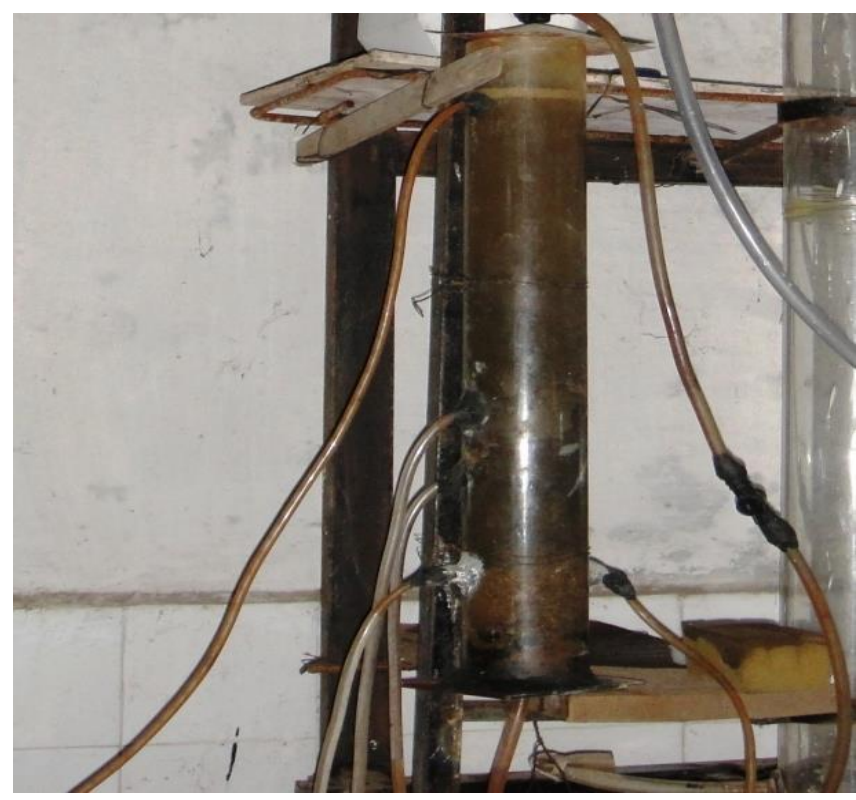

Fig. 1. Column Tracer Setup

\section{Glass column}

A fiber column having $400 \mathrm{~mm}$ diameter and height $300 \mathrm{~mm}$ was used and the soil was compacted by means of static compaction under controlled means.

\section{Storage tank}

The tank was made up of iron sheet with inside dimensions of $300 \times 300 \times 550 \mathrm{~mm}$ of 50 litres capacity was used to contain the solution. At the bottom of the test tank a small outlet is provided connecting glass column through a flexible tube of diameter $10 \mathrm{~mm}$. The tank is placed at a height of $1860 \mathrm{~mm}$ from the center of the outlet of the glass column.

\section{Flexible tube}

A flexible tube is used to transport the solution from storage tank to glass column. The test fluid was introduced vertically downward through a thin circular ring (called inlet tube) with an internal diameter of $51 \mathrm{~mm}$.

\section{Flow adjusting clamp}

A clamp was used to adjust the required velocity of flow.

\section{Air removing valve}

It is provided mainly to remove or avoid the entrapped air in the glass column without causing disturbance to the soil sample in the column. 


\section{International Journal of Engineering Applied Sciences and Technology, 2019 \\ Vol. 4, Issue 5, ISSN No. 2455-2143, Pages 486-492 \\ Published Online September 2019 in IJEAST (http://www.ijeast.com)}

\section{Properties of materials used}

In the present study the soil and nitrate $\left(\mathrm{No}_{3}-\right)$ are used to study the transport mechanisms of solution through soil media.

\section{Soil}

The soil used in the study was collected from Bidar, Karnataka in India. The soil is red and black in Colour and having the percentage fines (size $<0.075 \mathrm{~mm}$ ) of 75.64 and 60.24 respectively. The specific gravity of black cotton and red soils are 2.25 and 2.96 respectively. The physical properties of soil are tabulated in Table 1.

Table 1: Physical Properties of Black Cotton and Red Soils

\begin{tabular}{|c|c|c|c|}
\hline & Characteristics & $\begin{array}{c}\text { Black } \\
\text { cotton } \\
\text { soil }\end{array}$ & Red soil \\
\hline 1 & $\mathrm{P}^{\mathrm{H}}$ & 7.52 & 7.74 \\
\hline 2 & $\%$ of Silt \& Clay & 75.64 & 60.24 \\
\hline 3 & $\begin{array}{c}\text { Bulk density } \\
\left(\mathrm{kN} / \mathrm{m}^{3}\right)\end{array}$ & 10.92 & 11.41 \\
\hline 4 & $\begin{array}{c}\text { Specific gravity } \\
\left(\mathrm{gm} / \mathrm{m}^{3}\right)\end{array}$ & 2.25 & 2.96 \\
\hline 5 & Porosity & 0.5 & 0.6 \\
\hline 6 & Soil texture & Sandy & Clay \\
\hline
\end{tabular}

\section{Nitrate}

Nitrate was brought from the chemical research laboratory at Bhalki, India. The nitrate was brought in the form of powder and stored in an air tight bottle without destroying its initial form. The method which is used to determine the nitrate is Phenol Disulphonic Acid (PDA) method as mentioned in the following sections.

\section{Test Procedure}

Soil column was prepared in the fiber column and sample was allowed for saturation and upon ensuring the saturation, the solution was allowed to pass through the soil column. The nitrate concentrations were measured by using UVSpectrophotometer (SL-177) (Fig. 2).

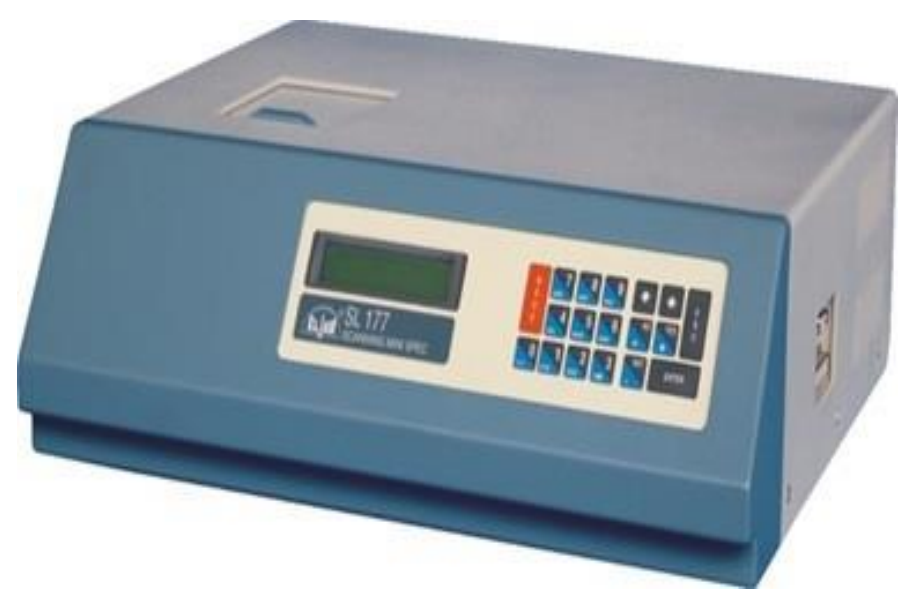

Fig. 2. Scanning UV- spectrophotometer (SL-177)

\section{Preparation of Soil Sample}

An air dried soil sample was collected and weighed. In a glass column with diameter of size of $400 \mathrm{~mm}$ and height $300 \mathrm{~mm}$, soil was accommodated by manual soil compaction.

\section{Saturation of the Soil Specimen}

The soil column was saturated with the help of arrangement made for flow to takes place in the test set- up. The saturation was ensured such that there was observed constant volume of water flow from the outlet. The arrangement was made to remove the entrapped air in the soil column.

\section{Determination of Nitrate (No3-)}

\section{Phenol Disulfonic Acid (PDA)}

$25 \mathrm{gms}$ of white nitrate was dissolved in $150 \mathrm{ml}$ of concentrated $\mathrm{H}_{2} \mathrm{SO}_{4}$. To this $75 \mathrm{ml}$ of fuming $\mathrm{H}_{2} \mathrm{SO}_{4}$ was added, stirred well and was heated for $2 \mathrm{hr}$ on water bath. If fuming $\mathrm{H}_{2} \mathrm{SO}_{4}$ is net available add additional $85 \mathrm{ml}$ concentration of $\mathrm{H}_{2} \mathrm{SO}_{4}$ to the $150 \mathrm{ml} \mathrm{H}_{2} \mathrm{SO}_{4}$ stir well and heat for $2 \mathrm{hr}$.

Retardation factor for column tracer experiment using Freundlich isotherm

Results obtained by column tracer method were interpreted using Freundlich and Langmuir isotherms to describe the adsorption of nitrate. In all cases of Nitrate adsorption, the best fit was obtained for the Freundlich isotherm, and the equation is given below Eqn. 1 .

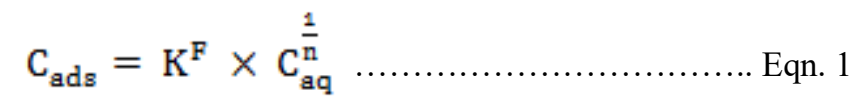

Where

$\mathrm{C}_{\mathrm{ads}}=$ Balance concentration of the studied compound in the ground. 


\section{International Journal of Engineering Applied Sciences and Technology, 2019 \\ Vol. 4, Issue 5, ISSN No. 2455-2143, Pages 486-492 \\ Published Online September 2019 in IJEAST (http://www.ijeast.com)}

$\mathrm{C}_{\mathrm{aqs}}=$ Balance concentration of the studied compound in the water.

$K^{F}$ and $n=$ coefficients of the Freundlich adsorption isotherm.

Substitute distribution coefficient (Determined using the Freundlich isotherm) $\mathrm{K}_{\mathrm{d}}{ }^{\mathrm{F}}$ for a given value of balance concentration of ion adsorbed in the solution equals.

$\mathrm{K}_{\mathrm{d}}^{\mathrm{F}}=\frac{\mathrm{K}^{\mathrm{F}} \mathrm{C}_{\mathrm{aqs}}^{\frac{1}{\mathrm{n}}}}{\mathrm{C}_{\mathrm{aqs}}}=\mathrm{K}^{\mathrm{F}} \mathrm{C}_{\mathrm{aqs}}^{\frac{(-1)}{\mathrm{n}}}$

For the distribution coefficient determined on the basis of the adsorption isotherm, the retardation has been defined as mentioned in Eqn. 3.

$\mathrm{R}=1+\frac{\rho_{\mathrm{d}}}{\mathrm{n}} \mathrm{K}_{\mathrm{d}}^{\mathrm{F}}$ Eqn. 3

\section{Adsorption isotherms}

The quantity of adsorbate that can be taken up by an adsorbent is a function of both the characteristic and concentration of adsorbate and the temperature. The characteristic of the adsorbate that are of importance includes solubility, molecular structure, molecular weight, polarity and hydrocarbon saturation. Generally the amount of adsorbate adsorbed by adsorbent is determined as the function of concentration at constant temperature, and the resulting function is called as the adsorption isotherm.

Adsorption isotherms are developed by exposing a given amount of adsorbate in a fixed volume of liquid to varying amounts of adsorbate. Equations that are often used to describe the experimental isotherm data were developed by Freundlich and Langmuir.

\subsubsection{Freundlich isotherm}

The general form of Freundlich equation is shown Eqn. 4.

$\mathbf{q}=\left(\frac{\mathrm{x}}{\mathrm{m}}\right)=\mathbf{K} \mathbf{C}^{\frac{1}{\mathrm{n}}}$ Eqn. 4

Where

$(\mathrm{x} / \mathrm{m})=$ Amount of solute adsorbed per unit mass of adsorbent in $\mathrm{mg} / \mathrm{g}$.

$\mathrm{C}=$ Equilibrium concentration of adsorbate in solution after adsorption in $\mathrm{mg} / \mathrm{l}$.

$\mathrm{K}=$ Freundlich capacity factor and $(1 / \mathrm{n})=$ Freundlich intensity factor.

The constants $\mathrm{K}$ and $\mathrm{n}$ in the Eqn. 5 can be evaluated by plotting amount of solute adsorbed per unit mass of adsorbent versus equilibrium concentration of adsorbate in solution after adsorption on a double logarithmic graph. The Freundlich equation is basically empirical but is often useful as means for data description. Data are usually fitted to the logarithmic form of equation.

$\log _{\mathrm{e}}(\mathrm{x} / \mathrm{m})=\log _{\mathrm{e}} \mathrm{K}+1 / \mathrm{n} \log _{\mathrm{e}} \mathrm{C}$ Eqn. (5)

\subsubsection{Langmuir isotherm}

Langmuir isotherm is based on the assumption that point of valance exists on the surface of the adsorbent and that each of these site is capable of adsorbing one molecule. It is assumed that the adsorption sites have equal affinities for molecules of adsorbate and that the presence of adsorbed molecules at one site will not affect the adsorption of molecules at an adjacent site. The Langmuir equation is commonly written as shown in Eqn. 6.

$\mathbf{q}=\left(\frac{\mathbf{x}}{\mathbf{m}}\right)=\frac{\mathrm{abc}}{1+\mathrm{bc}}($ or $) \frac{\mathrm{c}}{\mathrm{x} / \mathrm{m}}=\frac{1}{\mathrm{ab}}+\frac{\mathrm{c}}{\mathrm{a}} \ldots \ldots \ldots \ldots$ Eqn. 6

Where

$\mathrm{q}=$ Amount of solute adsorbed per unit mass of adsorbent in $\mathrm{mg} / \mathrm{g}$.

$\mathrm{C}=$ Equilibrium concentration of adsorbate in solution after adsorption in $\mathrm{mg} / \mathrm{l}$ and $\mathrm{a}$ and $\mathrm{b}$ are Langmuir constants related to capacity and energy of adsorption respectively. Plot of $\mathrm{C} /(\mathrm{x} / \mathrm{m})$ Vs $\mathrm{C}$ would give the value of constants. A dimensionless equilibrium parameter called separation factor, $\mathrm{R}$ is use to study the applicability of Langmuir adsorption isotherm.

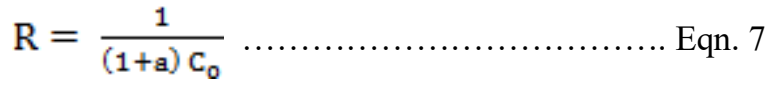

Where $\mathrm{a}=$ Langmuir constant

$\mathrm{C}_{\mathrm{o}}=$ Initial concentration

\section{EXPERIMENT AND RESULT}

A series of column tracer experiments have been performed with Nitrate on two different soils considered to obtain the breakthrough curves and retardation coefficients.

\section{Adsorption of Nitrate}

\section{Black cotton soil}

A series of column tracer experiments have been performed on Black cotton soil and values are plotted in Fig. 3 shows tracer breakthrough curve for $10 \mathrm{mg} / \mathrm{l}$ of initial concentration. From the graph it is observed that the time required for maximum adsorption to reach an equilibrium concentration $\left(\mathrm{C} / \mathrm{C}_{\mathrm{o}}\right)$ of 0.75 is $260 \mathrm{~min}$. 


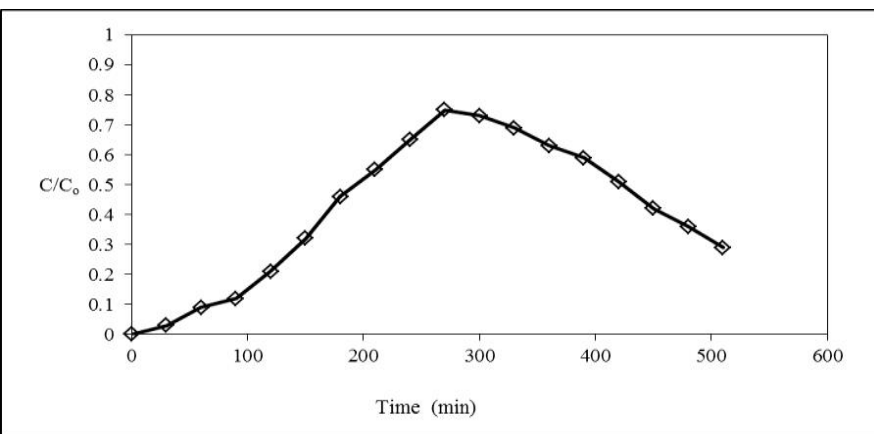

Fig. 3. Break through curve (BTC) for adsorption of nitrate in black cotton soil with initial concentration of $10 \mathrm{mg} / \mathrm{l}$.

The results obtained with different concentrations are fit to adsorption isotherms as mentioned in Fig. 4 and 5. Similar experiments were performed for concentrations of $10 \mathrm{mg} / \mathrm{l}$, the results of the tracer experiment are fit to Freundlich and Langmuir isotherms. From the Freundlich isotherm (Fig. 4) it is concluded that the equation $\mathrm{y}=0.995 \mathrm{x}^{1.001}$ with regression coefficient is 1 . The equation which was mentioned in Eqn. 1 satisfying the above expression, we get $\mathrm{K}^{\mathrm{F}}=0.995$ and the same value substituted in Eqn. 2. Finally the $\mathrm{K}_{\mathrm{d}}{ }^{\mathrm{F}}=0.840$ from Eqn. 3 we get retardation value $\mathrm{R}=2.089$.

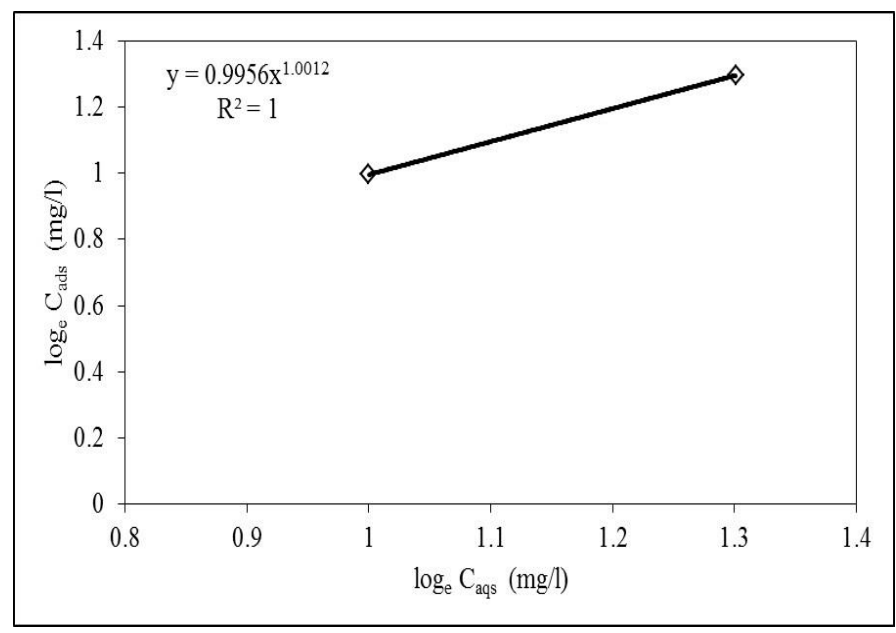

Fig. 4.Freundlich isotherm for Nitrate adsorption in black cotton soil.

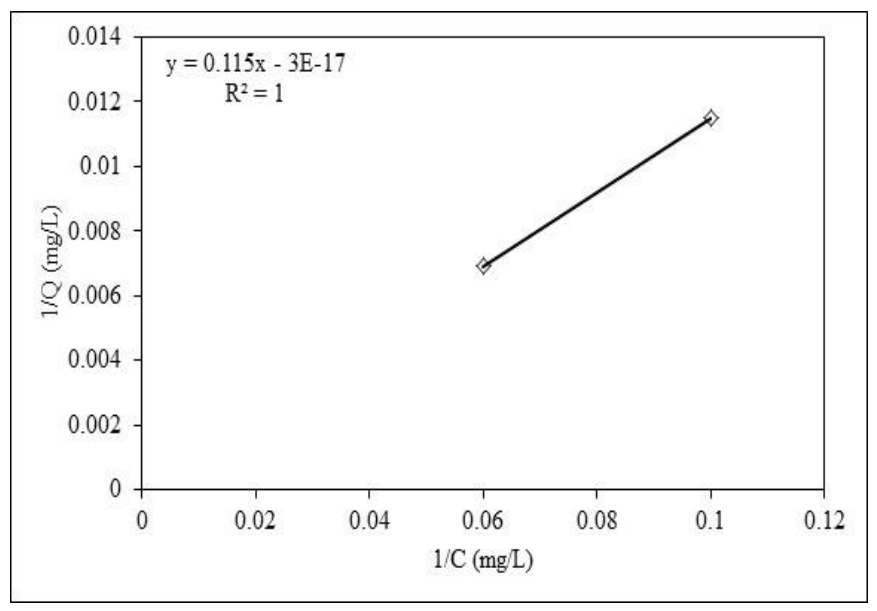

Fig. 5.Langmuir isotherm for nitrate adsorption in black cotton soil

The tracer experiments were carried out on black cotton (BC) soil of the properties given in Table 1 with the tracer concentration of $10 \mathrm{mg} / \mathrm{l}$ respectively. Table 2 shows the results of the single adsorption of nitrate in black cotton (BC) soil to fit the results to the Langmuir isotherm. The results are plotted as shown in Fig. 5 and is fit to Eqn. 7 given by, $1 / \mathrm{Q}=0.4592,1 / \mathrm{C}=0.016$ where the regression coefficient 1 from the fit we obtained Langmuir constants, $a=25$ and $b=0.2$ and $\mathrm{R}=0.0384$.

Table 2: Adsorption of Nitrate for selected concentrations and soils to fit Freundlich isotherm

\begin{tabular}{|c|c|c|}
\hline $\begin{array}{c}\text { Initial } \\
\text { concentration } \\
(\mathbf{m g} / \mathbf{L}) \\
\log _{\mathrm{e}} \mathbf{C}_{\mathbf{a q s}}\end{array}$ & $\begin{array}{c}\text { Black cotton soil } \\
(\mathbf{m g} / \mathbf{L}) \\
\log _{\mathrm{e}} \mathbf{C}_{\mathrm{ads}}\end{array}$ & $\begin{array}{c}\text { Red soil }(\mathbf{m g} / \mathbf{L}) \\
\log _{\mathrm{e}} \mathbf{C}_{\mathrm{ads}}\end{array}$ \\
\hline 1.000 & 0.9956 & 0.991 \\
\hline 1.301 & 1.2957 & 1.2981 \\
\hline
\end{tabular}

\section{Red Soil}

A series of column tracer experiments have been performed on red soil and values are plotted in Fig. 6 shows tracer breakthrough curve for $10 \mathrm{mg} / \mathrm{l}$ of initial concentration. From the graph it is observed that the time required for maximum adsorption to reach an equilibrium relative concentration $\left(\mathrm{C} / \mathrm{C}_{\mathrm{o}}\right)$ of 0.75 is $310 \mathrm{~min}$. 


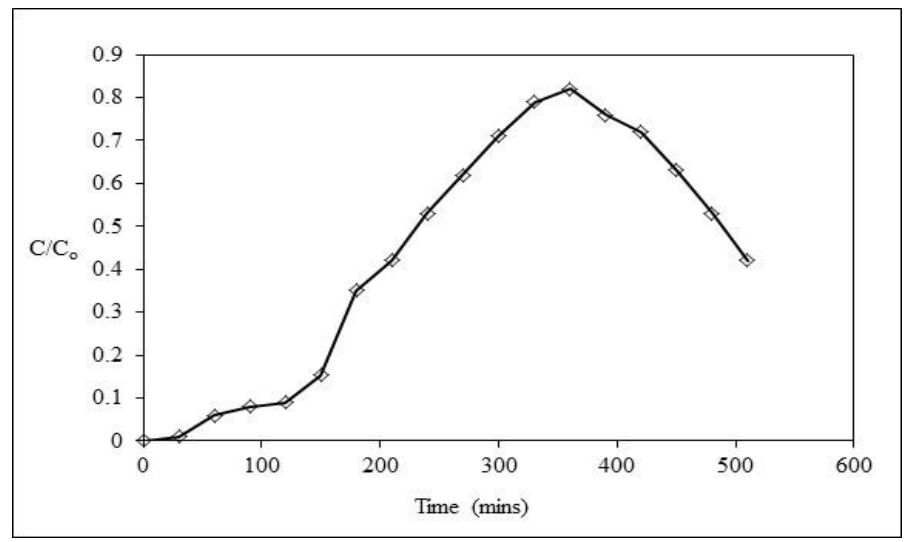

Fig. 6. Break through curve (BTC) for nitrate adsorption in red soil with the initial concentration of $10 \mathrm{mg} / \mathrm{l}$.

Similar experiments were performed for concentrations of 10 $\mathrm{mg} / \mathrm{l}$, the results of the tracer experiment are fit to Freundlich and Langmuir isotherms as shown in Fig. 7 and 8 and the results are analyzed. From Freundlich isotherm $y=0.991 C^{1.025}$ which is in the form $C_{a d s}=K^{F} \times C_{a q}^{1 / n}$ Where from equation 1 we get $\mathrm{K}^{\mathrm{F}}=0.61$ and $1 / \mathrm{n}=1.025$ and from Eqn. 2 we get $K_{d}^{F}=0.624$ from Eqn. 3 we get retardation value $\mathrm{R}=2.018$.

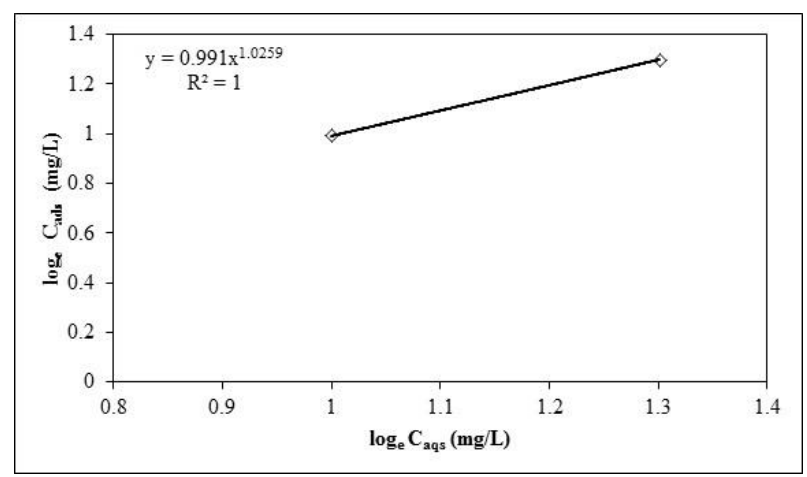

Fig. 7. Freundlich isotherm of nitrate adsorption in red soil

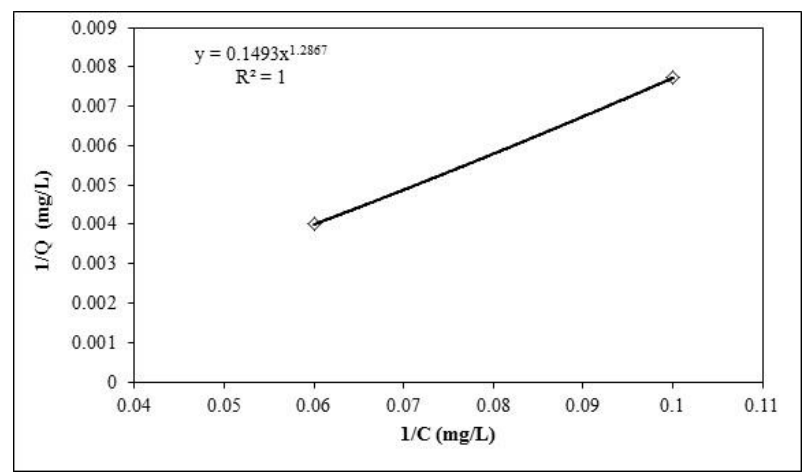

Fig. 8. Langmuir isotherm of nitrate adsorption in red soil.
The tracer experiments were carried out on red soil of the properties given in Table 1 with the tracer concentration of $10 \mathrm{mg} / \mathrm{l}$ respectively. Table 3 shows the results of the single adsorption nitrate in red soil to fit the results to the Langmuir isotherm. The results are plotted as shown in Fig. 8 and the corresponding values are fit to Eqn. 7 given by $1 / \mathrm{Q}=0.0923$, $1 / \mathrm{C}=0.001$ where the regression coefficient is 1 . From the fit we obtained Langmuir constants, $a=17.14 \mathrm{~b}=0.145$ and the retardation value $\mathrm{R}=0.0055$. Table 3 shows the results of the Single adsorption of Nitrate for selected concentrations and soils to fit Freundlich isotherm.

Table -3 Adsorption of Nitrate for selected concentrations and soils to fit Langmuir isotherm

\begin{tabular}{|c|c|c|}
\hline $\begin{array}{c}\text { Initial } \\
\text { concentration } \\
(\mathbf{m g} / \mathbf{L})\end{array}$ & $\begin{array}{c}\text { Black cotton } \\
\text { soil }(\mathbf{m g} / \mathbf{L})\end{array}$ & Red soil in $(\mathbf{m g} / \mathbf{L})$ \\
\hline $1 / \mathrm{C}$ & $1 / \mathrm{Q}$ & $1 / \mathrm{Q}$ \\
\hline 0.2 & 0.07342 & - \\
\hline 0.1 & 0.03347 & 0.04 \\
\hline 0.0666 & 0.01666 & 0.015 \\
\hline 0.05 & 0.0105 & 0.0096 \\
\hline
\end{tabular}

From the aforementioned discussions we observed that the column tracer experiment with black cotton soil takes less time to reach equilibrium than red soil. This is mainly due to the basic soil characteristics of both black cotton soil and red soil i.e., surface area, bulk density and porosity. Similarly from the both Langmuir and Freundlich isotherms it is evident that the retardation factor is affected by the percentage fines available in soil. If the percentage fines of the soil are more than the adsorption capacity will be more.

\section{CONCLUSION}

The conclusions from the study can be summarized as follows: From both the soils black cotton soil having good adsorption capacity as compared to red soil. It was observed that the maximum amount of nitrate was leached through black cotton soil followed by red soil. In column tracer experiments results of Langmuir isotherm and Freundlich isotherm holds good.

\section{REFERENCE}

[1] R. Rautenbach, W. Kopp, R. Hellekes, R. Peter, G. Vanopbergen,. (1986). Separation of nitrate from well water by membrane processes (Reverse Osmosis/ Electro dialysis Reversal), Aqua 5, (pp.279-282).

[2] D.P. Summers, S. Chang, (1993) .Prebiotic ammonia from reduction of nitrate by iron (II) on the early earth, Nature 365, (pp.630-632).

[3] M. Shrimali, K.P. Singh, (2001). New methods of nitrate removal from water, Environ. Pollution,(pp.351-359). 
[4] L. Fewtrell, (2004). Drinking-water nitrate, methemoglobinemia, and global burden of disease: a discussion, Environ. Health Perspective.(pp.1371-1374).

[5] N. Ozturk, T.E. Bektas, (2004), Nitrate removal from aqueous solution by adsorption on to various materials, J. Hazard. Mater. (Pp.155-162).

[6] J.V. Rijn, Y. Tal, H.J. Schreier, (2006) Denitrification in recirculating systems: theory and applications, Aquacult. Eng. (pp.364-376).

[7] S. Ahlgren, A. Baky, S. Bernesson, A. Norberg, O. Norén, P.-A. Hansson, (2008) Ammonium nitrate fertilizer production based on biomass-environmental effects from a life cycle perspective, Bioresour. Technol.(pp. 8034-8041).

[8] S. Chatterjee, S.H. Woo, (2008) The removal of nitrate from aqueous solutions by chitosan hydrogel beads, J. Hazard. Material.

[9] S. Ghafari, M. Hasan, M.K. Aroua, (2008) Bioelectrochemical removal of nitrate from water and wastewater - a review, Bioresour. Technol. (pp.39653974).

[10] S Stadler, K C Osenbru, K Knoller, A Suckow, J Sultenfuß, H Oster, T Himmelsbach and H Hotzl, (2008) Understanding the origin and fate of nitrate in groundwater of semi-arid environments, Journal of Arid Environments ,(pp.1830-1842)

[11] Blanca Prado,Céline Duwig ,Mauricio Escudey \&Michel Esteves ,(2011), Nitrate Sorption in a Mexican Allophanic Andisol using Intact and Packed Columns,(pp.29112925).

[12] Morteza Mohsenipour, 1 Shamsuddin Shahid, 1 and Kumars Ebrahimi2, (2015), Nitrate Adsorption on Clay Kaolin: Batch Tests, Journal of Chemistry, Article ID 397069, 7 pages. 